\title{
ПРОБЛЕМА ВЗАЕМОВПЛИВІВ ЛЮДСЬКИХ ПОТРЕБ, ІНТЕРЕСІВ ТА ПРАВОВОГО РЕГУЛЮВАННЯ В ІСТОРІЇ ЮРИДИЧНОЇ ДУМКИ (СТИСЛИЙ ЕКСКУРС)
}

\section{Рабінович П. М., Наконечна А. М.}

\section{ВСТУП}

Українське суспільство перебуває в непростих умовах, пов'язаних із його євроінтеграційними прагненнями, перебудовою державного та суспільного ладу, трансформацією економічних відносин відповідно до ліберальних цінностей. Ці умови дають додаткову підставу замислитись над покликанням сучасного позитивного правового регулювання в життєдіяльності кожної людини та суспільства загалом.

Один із можливих дослідницьких шляхів у пошуку відповіді на ці питання видається у філософсько-правовому аналізі правового регулювання крізь призму людських потреб.

Потреби чи, точніше, процес їх задоволення становлять значну частину життя кожної людини. Саме вони задають ритм життя людини й суспільства загалом. Тому і не дивно, що потреби вже досить давно потрапили у поле зору мислителів, які розглядали їх як своєрідний ключ до вирішення фундаментальних питань людства.

Питання про роль потреб у правовому регулюванні торкалися так чи інакше численні правники-науковці, зокрема ті, які розробляли аксіологоправову проблематику (С.С. Алексєєв, В.М. Баранов, В.Д. Зорькін, Д.А. Керімов, М.І. Козюбра, В.М. Кудрявцев, В.О. Кучинський, О.А. Лукашова, Г.В. Мальцев, Л.С. Мамут, М.І. Матузов, В.С. Нерсесянц, Ю.М. Оборотов, М.П. Орзіх, П.М. Рабінович, О.Ф. Черданцев, Л.С. Явич та ін.).

Проте у вітчизняній юридичній науці проблема потреб у праві ще не була предметом монографічного дослідження, тому низка питань, які стосуються цієї проблеми, досі залишаються нез'ясованими.

\section{1. Античний період та Середньовіччя}

Проблема потреб й інтересів проявляє себе в античний період розвитку філософії (VII ст. до н.е. - V н.е.) в руслі матеріалістичних поглядів і була пов'язана насамперед 3 філософськими уявленнями про гедонізм i евдемонізм, згідно з якими людська поведінка визначається потягом до насолоди і щастя. 
Давньокитайський філософ Мо-цзи виділив три потреби простого народу: «голодні не мають їжі, замерзлі не мають одягу, втомлені не мають відпочинку» ${ }^{1}$. Він стверджував, що потреби можна задовольнити тільки в «старанній праці». «Хто старанний в праці, той має можливість жити, а хто не старанний в праці, той не має можливості жити»².

Античний мислитель Антифонт стверджував, що «у всіх людей потреби від природи однакові. <..> I справді, ми всі однаково дихаємо повітрям через рот і ніс і їмо ми всі однаково - за допомогою рук» ${ }^{3}$.

Демокріт розглядав потреби як брак чогось, вважав, що ті є джерелом дій людини: «Справді, сама нужда слугувала людям вчителькою у всьому, скеровуючи їх відповідним чином до пізнання кожної речі...» ${ }^{4}$. При цьому Демокріт звертав увагу на відмінність самої потреби від засобів іiі задоволення, вказуючи на те, що «людина не знає меж задоволення своїх потреб» ${ }^{5}$.

Послідовник Демокріта Епікур пов'язував життєдіяльність людини із задоволенням, при цьому розрізняючи потреби природні і необхідні - ті, які позбавляють людину страждань; природні, але не необхідні - ті, які урізноманітнюють насолоду; неприродні і не необхідні - влада, багатство, розваги тощо ${ }^{6}$.

Сутність концепції Епікура полягає в обов'язковому задоволенні необхідних потреб, інакше кажучи, людина може задовольнятися малим і отримувати задоволення від звичайних речей: «Шлях до щастя можливий тоді, коли людина, керуючись розумом і волею, задовольняє ці природні і необхідні потреби» 7 . Невипадково в працях прихильників гедонізму з'являється таке поняття, як «атараксія» - некерований стан душі.

Фактично саме в рамках розвитку матеріалістичного напряму відбувалось формування уявлень про потреби як детермінанту діяльності людини. Однак з огляду на те, що ці дослідження були початковими спробами у вирішенні питання про роль потреб у діяльності, то для філософів було природно розглядати потребу як нужду. Це був на той момент найпростіший шлях до розуміння сутності потреб.

Проблемою потреб у період античності зацікавились також філософиідеалісти, які розглядали потреби як невід'ємний складник людської

\footnotetext{
${ }^{1}$ Мо-дзи. Критика родовой знати и конфуцианства. Антология мировой философии: в 4 т. Москва : Мысль, 1969. Т. 1. Ч. 1. С. 197.

${ }^{2}$ Там само. С. 200.

${ }^{3}$ Антифонт. Антология мировой философии: в 4 т. Москва : Мысль, 1969. Т. 1. Ч. 1. С. 320-321. С. 321.

4 Лурье С.Я. Демокрит. Тексты. Перевод. Исследования. Ленинград : Ленинградское отделение издательства «Наука», 1970. С. 739.

5 Дынник М.А. Материалисты Древней Греции. Москва : Госполитиздат, 1956. С. 43.

${ }^{6}$ Богомолов А.С. Антическая философия. Москва : Изд-во МГУ, 1985. С. 254.

${ }^{7}$ Богомолов А.С. Антическая философия. Москва : Изд-во МГУ, 1985. С. 254.
} 
діяльності. Поза тим основний акцент у своїх вченнях вони робили на розмежуванні тваринних і людських потреб, маючи на меті показати особливості саме людських дій. При цьому філософи пов'язували ці особливості $з$ початком діяльності. Подібний підхід до питання про потреби був зумовлений, з одного боку, недостатнім знанням про механізм розвитку діяльнісного процесу; 3 іншого - загальною установкою на визначальну роль ідеальних категорій. Наприклад, предтечею гедоністичних поглядів про потреби стали постулати Платона, для якого потреби були основоположним елементом формування держави, незважаючи на те, що він був прихильником крайніх ідеалістичних поглядів. За Платоном, держава «виникає тоді, коли кожний з нас не може задовольнити сам себе, але потребує ще багато чого. Таким чином, кожна людина залучає то одного, то іншого для задоволення тієї чи іншої потреби...» ${ }^{8}$. При цьому Платон визначає подвійне начало в людині як можливість розмежування природних інстинктів і того, що становить іiі самоцінність: «одне з них, за допомогою якого людина здатна мислити, ми назвемо розумним началом душі, а друге, через яке людина закохується, відчуває голод i спрагу та буває охоплена іншими бажаннями, ми називаємо < ..> бажаним» ${ }^{9}$. Оскільки для Платона потреба - це нужда, він визначає наявність базових потреб за принципом їх зростання: «Перша i найбільша потреба - це здобуття їжі для існування і життя; друга потреба житло, третя - одяг і так далі» ${ }^{10}$. Втім подібне твердження дало змогу філософу розвинути ідею про те, що кількість бажань суб'єкта необмежена. Причину цього Платон вбачав у прагненні людини до «особистісної корисливості», що, на його думку, було зумовлене природою людини, i тільки за допомогою закону $є$ можливість «насильницьким чином змусити їі дотримуватись належної міри» ${ }^{11}$.

Надалі проблемою потреб займався Аристотель, який, як і Платон, вважав, що людина і тварина наділені різними потребами, у зв'язку з цим він поділяв потреби на природні й істинно людські. Для нього це була спроба, як і для Платона, визначити суть відмінності дій людини від дій тварин, оскільки Аристотель звертав увагу на той факт, що «у інших живих істот нема ані мислення, ані здатності розмірковувати» ${ }^{12}$. При цьому, на відміну від ідеалістичних позицій Платона щодо питання про

\footnotetext{
${ }^{8}$ Платон. Сочинения: в 4 т. Санкт-Петербург : Изд-во С.-Петерб. ун-та; «Изд-во Олега Абышко», 2007. Т. 3. Ч. 1. С. 145.

${ }^{9}$ Платон. Сочинения: в 4 т. Санкт-Петербург : Изд-во С.-Петерб. ун-та; «Изд-во Олега Абышко», 2007. Т. 3. Ч. 1. С. 145.

10 Там само.

11 Там само.

${ }^{12}$ Аристотель. Сочинения: в 4 т. Москва : Мысль, 1981. Т. 3. С. 442.
} 
роль потреб у діяльності, Аристотелю властива подвійна позиція стосовно взаємозв'язку потреби з практичною діяльністю людини, виражена в коливанні між матеріалізмом та ідеалізмом. О.I. Самсін виявляє цю особливість у тому, що Аристотель, з одного боку, говорить про природне походження людських бажань, а 3 іншого - абсолютного значення надає душевним прагненням, серед яких вищий ступінь чесноти в пошуку істини $^{13}$. Поряд 3 цим Аристотель визначає потребу як єдину міру всього, яка сприяє встановленню суспільних взаємин і процесу обміну. Притому Аристотель пояснює, що причиною звернення саме до потреби в такому контексті є те, що все повинно вимірюватися чимось одним, і такою мірою $\epsilon$ потреба, «яка все пов'язує разом, бо, якби не було у людей ні в чому нужди,.. тоді або не буде обміну, або він буде не таким» ${ }^{14}$.

Ідеалістична традиція Платона знайшла своє продовження в період розвитку середньовічної філософії (V-XV ст.), де першочергове значення набули духовні потреби й інтереси, які різко протиставлялись матеріальним. 3 позиції християнської етики вищим благом вважалась потреба в любові ${ }^{15}$.

\section{2. Період Нового часу}

Істотний поступ у розвитку уявлень про потреби відбувся в європейській філософії Нового часу (XVI - початок XX ст.) у руслі матеріалістичного напряму, зачинателем якого став Ф. Бекон, який, як і його наступники, розглядав поняття «потреба» як ланку у формуванні суспільства. При цьому він вважав, що наявні три види благ, які люди очікують для себе від громадянського суспільства: позбавлення від самотності, допомога у справах і захист від тих, хто ображає ${ }^{16}$. Однак філософ враховував той факт, що свідомість у разі реалізації потреби в діяльності відіграє значну роль, адже розум за свідомості дає людині більш істинну і природну радість, ніж усі ті намагання і засоби, які людина «може вживати для задоволення своїх бажань чи досягнення душевного спокою» ${ }^{17}$. Разом із тим Ф. Бекон указав на те, що потребу треба сприймати як даність, оскільки ії не можна скасувати: «І навіть у суто природних процесах <..> легше обдурити природу, ніж грубо придушити іiі, i, таким чином, те, що реалізується надто прямо, виявляється часто невдалим і таким, що завдає

\footnotetext{
${ }^{13}$ Самсин А.И. Социально-философские проблемы исследования потребностей. Москва : Высшая школа, 1987. С. 6.

${ }^{14}$ Аристотель. Сочинения: в 4 т. Москва : Мысль, 1983. Т. 4. С. 156.

${ }_{15}$ Августин Аврелий. Исповедь. URL: http://azbyka.ru /otechnik/?Avrelij_Avgustin/ispoved.

16 Бэкон Ф. О достоинстве и приумножении наук. URL: httpt//www.vostlit.info/Texts/rus7/Bacon/ frametext2.htm/

17 Там само.
} 
шкоду самому собі, тоді як обхідний і поступовий шлях буває зручнішим i ефективнішим» ${ }^{18}$.

Надалі людські потреби й інтереси розглядались у працях матеріалістівпросвітителів (Д. Дідро, К. Гельвецій, П. Гольбах), які вивчали вплив людських потреб на формування суспільства 3 позиції «розумного егоїзму». Так, П. Гольбах указував на факт того, що можливість жити людині в умовах суспільних відносин сприяє розвитку не тільки самих потреб, а й засобів їх задоволення. Філософ у своєму дослідженні «Система природи» підкреслював, що природа посилає людину голою і безпомічною в цей світ, але, «... живучи в багатих досвідом суспільствах і потопаючи насамкінець у розкоші, вони 3 кожним днем придумують тисячі нових потреб і відкривають тисячі нових способів задоволення їх...»19. При цьому філософ звертав увагу на те, що людина повинна шукати в самій природі і в своїх силах засоби задоволення своїх потреб. Така позиція зумовлена насамперед тим, що в період Нового часу дістала поширення думка про те, що «соціальне» $\epsilon$ визначальним i тому вплив суспільства на людину розглядався як детермінуючий, отже, всі бажання і прагнення, властиві людині, вважались абсолютно залежними від розвитку суспільних відносин, що, на думку П. Гольбаха, не завжди було для людини конструктивним. Притому П. Гольбах відповідно до своєї позиції вперше розділив потреби на «першочергові», які мають природне начало, і «другорядні».

Д. Дідро, своєю чергою, також схвалював подібний поділ потреб, щоправда, розмежовуючи їх не так конкретно, як П. Гольбах. Так, він виділяв необхідні потреби, тобто ті, які «не виходять за розумні межі», i ті, які породжують прагнення до розкоші. При цьому Д. Дідро називав розкішшю все те, що перевершує необхідні потреби людини - необхідні 3 точки зору становища, яке займає кожний громадянин у суспільстві. Отже, він вважав: «Не можна говорити про розкіш у багачів, якщо в задоволенні своїх смаків, пристрастей <..> вона не виходить за розумні межі, приписувані ій іiї багатством... Зовнішній вигляд стирає межу між станами. Щоб підтримати цю видимість, чоловіки і жінки, вельможі і прості люди проституюють на сотні ладів. Соромляться тільки нужди» ${ }^{20}$. Тим самим Д. Дідро загострює соціальний характер потреб, сприяючи здійсненню бажання людини відчувати себе самодостатньою в суспільстві.

Якщо П. Гольбах говорив про тисячу нових потреб, то К. Гельвецій вказував тільки на одну фізичну потребу, здатну об’єднувати людей в

\footnotetext{
18 Там само.

${ }^{19}$ Гольбах П.А. Избранные произведения: в 2 т. / под общей редакцией и со вступительной статьёй Х.Н. Момджяна. Перевод с французского П.С. Юшкевича. Москва : Издательство «Мысль», 1963. Т. 1. С. $73-75$.

${ }^{20}$ Дидро Д. Последовательное опровержение книги Гельвеция «О человеке». Соч. в 2 т. Москва : Мысль, 1991. Т.2. С. 469-470.
} 
суспільство. При цьому він стверджував, що для кожного народу є деяка фізична потреба, яку можна розглядати як загальний двигун цього народу: «У диких народів Сходу, які часто були змушені голодувати i були постійно зайняті полюванням i виловлюванням риби, всі ідеї породжуються голодом, а не любов'ю; навпаки, у цивілізованих народів любов до жінок становить чи не єдиний двигун» ${ }^{21}$. Вважаємо, що перше висловлювання надто категоричне, оскільки, згідно 3 ним, можна стверджувати, що людина має безмежну кількість потреб, тоді як суб'єкт володіє визначеним набором базових потреб, інші ж є лише наслідком закономірного розвитку потреби в процесі діяльності на рівні актуалізації.

У працях французьких матеріалістів-просвітителів другої половини XVIII ст. також згадувалося про роль потреб у людській діяльності. Наприклад, Ж.-Ж. Руссо відзначав, що розвиток людських можливостей зумовлений життєвими потребами. Вольтер розмірковував про природні потреби людини, тобто ті, які сприяють забезпеченню спільної життєдіяльності людей: «Пристрасті - це вітри, які надувають вітрильники корабля, - заперечив відлюдник...- Іноді вони його топлять, але без них він не міг би плавати... Насолода - дар божества...» ${ }^{22}$.

Та попри те, що всі згадані вище мислителі вказували так чи інакще на людські потреби та інтереси, якими зумовлюється людська поведінка, вони, однак, не звертали увагу на залежність стану задоволення таких потреб та інтересів від позитивного права, правового регулювання.

Одним з перших політичних діячів (наскільки нам вдалося встановити 3 аналізу літератури з історії політичних і правових учень), які вказали на потребовий аспект позитивно-правового регулювання, був Ж.-П. Марат. Він, зокрема, стверджував, що закони мають бути справедливими, пов'язаними з благом суспільства, забезпеченими належним виконанням. Він наполягав на відповідальності суспільства за соціальний захист громадян, захист їхньої власності. Основними громадянськими правами, на його думку, $\epsilon$ права на особисту безпеку, свободу, власність, що $\epsilon$ природними правами людини. Забезпечуватися вони мають незалежним судом. Єдиним обмеженням свободи людини в суспільстві, як підкреслює мислитель, є заборона завдавати шкоду іншим ${ }^{23}$.

М. Робесп'єр вважав, що важливою основою громадянських прав $\epsilon$ індивідуальна і суспільна свобода, а також потреби людини. Головними засадами розбудови нової держави (політичного союзу), згідно з його

\footnotetext{
${ }^{21}$ Там само

22 Вольтер В. Философские повести. URL: https://fb2-epub.ru/publ/serija_knig/serija_filosofskie_ povesti_volter/2-1-0-195.

23 Історія вчень про державу i право : підручник / за ред. проф. Г.Г. Демиденка, проф. О.В. Петришина. Харків: Право, 2009. С. 105.
} 
поглядами, є: 1) охорона та забезпечення природних прав громадянина ${ }^{24}$; 2) право кожного громадянина на участь у законодавстві й управлінні, зумовлене природною рівністю і природженою свободою людей; 3) верховенство влади народу в державі ${ }^{25}$.

Як відзначав М. Михайлов: «Французькі матеріалісти не сумніваються, що низка потреб породжуються суспільством, але домінуючими потребами вважають природні нужди людини, які визначають іiі суспільне життя і потребують розвитку за «природними законами» ${ }^{26}$.

Представник німецької класичної філософії І. Кант у своїх працях стверджував, що взаємини серед людей встановлюються тільки заради задоволення потреб. Інакше кажучи, за І. Кантом, одна людина для іншої становить усього лише засіб задоволення потреб; саме тому люди об'єднуються в суспільства. Крім того, І. Кант говорить про природну схильність людей до тих чи інших потреб, тим самим виявляючи вроджений характер потреби: «Можливо, скажуть, що це відбувається і в тому випадку, коли об'єкт природи цікавить нас своєю красою лише настільки, наскільки 3 нею пов'язують моральну ідею; однак не це викликає безпосередній інтерес, а властивість природи сама по собі те, що вона допускає такий зв'язок, котрий внутрішньо їй властивий» ${ }^{27}$. Поза тим I. Кант ставив потреби в залежність від навколишнього середовища, тим самим применшуючи значення потреб у людській діяльності: «Доволі рано розвиваються у людини ті властивості, за допомогою яких вона може задовольнити потреби, які викликаються залежністю від зовнішніх речей...» ${ }^{28}$. У такому контексті виявляється суперечність позиції, яка полягає в тому, що, з одного боку, І. Кант розглядав потребу як вроджену властивість; з іншого боку, він сам заперечує таке твердження через обгрунтування залежності потреби від навколишнього середовища.

Вивчення людських потреб отримало своє продовження у філософії Г.-В.-Ф. Гегеля. Він не тільки стверджував факт існування потреб та їх природний характер, а й намагався визначити місце і роль потреби в людській діяльності. Попри ідеалістичний характер його позиції, він визнавав основоположну роль потреби в діяльності суб'єктів та виходив 3 того, що потреба становить продукт свідомості, а наявність тих чи інших потреб залежить від стану сприйняття.

\footnotetext{
${ }^{24}$ Там само. С. 106.

25 Демиденко Г.Г. Історія вчень про право і державу : навчальний посібник. Харків : Консум, 2004. C. 194

${ }^{26}$ Михайлов Н.Н. Потребности личности: проблемы формирования. Челябинск, 1981. С. 8.

${ }^{27}$ Кант И. Критика чистого разума. URL: http://philosophy.ru/library/kant/02/0.html.

${ }^{28}$ Кант И. Критика практического разума. URL: http://philosophy.ru/library/kant/02/0.html.
} 
Г.-В.-Ф. Гегель класифікував усі потреби на такі 4 групи: 1) фізичні, 2) потреби права, законів, 3) релігійні, 4) потреби пізнання. У зв'язку з цим варто звернути особливу увагу на те, щзо в иій класифікації мало не вперше виділено в окремий різновид людських потреб потреби у праві та у законі!

Він вважав, що потреба і предмет потреби становлять потребу взагалі, тобто це певне синтетичне ціле. Однак, на нашу думку, повинна бути чітка межа між матеріальними і духовними предметами потреби та самою потребою. Навіть попри твердження Гегеля про першочергову роль свідомості, його дослідження потреб зробили істотний внесок у розуміння їхньої значущості в людській діяльності. При цьому філософ підкреслював, що ті чи інші дії суб'єкта викликані саме потребами: «Якщо вчинення дій, які безпосередньо стосуються наших потреб, не пов'язане 3 якою-небудь ціллю, а регулюється безпосередньо, то цілеспрямоване воно визначене уявленнями» ${ }^{29}$.

Активний розвиток поглядів про потреби відбувся в працях німецьких філософів-матеріалістів. Зокрема, Л. Фейєрбах займався вивченням ролі потреби в людській діяльності. При цьому він визначив людину як частину природи, психофізіологічну істоту. Л. Фейєрбах говорив про те, що саме відчуття залежності припускає наявність людських потреб, які вимагають свого задоволення. Вся багатоманітність людських потреб зводиться Фейєрбахом, у кінцевому підсумку, до потягу до щастя. Крім того, Л. Фейєрбах розглядав потребу як першопричину людської діяльності, істинну сутність людини, він зумів розрізнити потребу і предмет потреби: «Де нема потреби, нема і відчуття залежності... Потреба є стільки ж служниця, скільки і господиня свого предмета, стільки ж смиренна, як і зверхня й зарозуміла, нещасна, в цьому полягає іiі вірне підданство, іiі самопожертва, відсутність егоїзму. Але вона потребує його, щоб отримати в ньому задоволення, щоб його використати, щоб його найкращим чином уподібнити....» ${ }^{30}$.

Уявлення про роль потреб й інтересів у людській діяльності поглибили відомі представники англійського лібералізму Дж. Бентам та Дж.-С. Мілль.

Дж. Бентам вважається засновником теорії утилітаризму, відповідно до якої критерієм для оцінювання будь-якої людської дії $\epsilon$ можливість досягнення якомога більшого щастя найбільшою кількістю людей.

Утилітаризм (від англ. utility - корисність) $є$ напрямом соціальної філософії, що виходить 3 того, що в основі будь-яких суспільних процесів лежить досягнення користі.

\footnotetext{
${ }^{29}$ Гегель Г.В.Ф. Философия религии: в 2 т. Москва : Издательство «Мысль», 1975. Т. 1. С. 392.

${ }^{30}$ Фейербах Л. Лекции о сущности религии. URL: http://lib.ru/HRISTIAN/ATH/lectures.txt_with-bigpictures.html.
} 
Методологічну основу бентамівської етичної філософії становлять два постулати:

a) причиною людських дій $є$ прагнення до отримання найбільшого задоволення та до мінімізації страждань;

б) саме задоволення мотивує існування політичних інститутів, влади, законодавства тощо.

Бентам пропонував пом'якшити досягнення індивідуальної користі користю суспільною. Отримання найбільшого задоволення та мінімізація страждань більшістю людей імплікує обов'язок кожного окремого громадянина відмовитись від досягнення миттєвої користі ${ }^{31}$.

Дж.-С. Мілль почав свою наукову діяльність як прибічник бентамівського утилітаризму, але згодом він відходить від нього. Філософ дійшов висновку, що не можна всю моральність формувати цілковито лише на постулаті особистої економічної вигоди індивіда і на вірі в те, що задоволення корисного інтересу кожної окремої людини мало не автоматично приведе до благополуччя всіх. На його думку, принцип досягнення особистого щастя може зреалізуватись, якщо тільки він нерозривно, органічно пов'язаний з іншою провідною ідеєю - ідеєю необхідності узгодження інтересів, при цьому узгодження не тільки інтересів окремих індивідів, а також й інтересів соціальних.

Усе це можливе тільки для вільної людини. Свобода індивіда - це «командна висота», з якої Мілль розглядає ключові для нього політичні та правові проблеми. I тут знову ж варто наголосити, що він своӥм останнім твердженням теж дав підставу віднести його до тих суспільствознавиів, які констатували той чи інший зв'язок між людськими потребами, з одного боку, та правовими явищами - з іншого.

Індивідуальна свобода, в трактуванні Мілля, означає абсолютну незалежність людини у сфері тих дій, які безпосередньо стосуються тільки iï самої; вона означає можливість людини бути у межах цієї сфери самій собі господарем і діяти в ній на власний розсуд. Межами індивідуальної свободи Мілль визначає такі іiі характеристики, як: свобода думки i переконання, виражена назовні, свобода діяти узгоджено 3 іншими індивідами, свобода вибору і досягнення життєвих цілей, самостійне влаштування власного життя. Усі ці свободи - абсолютно необхідні умови для розвитку, самореалізації індивіда та разом із тим захисту від усяких посягань ззовні на автономію особистості. ${ }^{32}$

\footnotetext{
31 Бентам И. Введение в основания нравственности и законодательства. Москва : «Российская политическая энциклопедия» (РОССПЭН), 1998.

${ }^{32}$ Політична енциклопедія. / Редкол.: Ю. Левенець (голова), Ю. Шаповал (заст. голови) та ін. Київ : Парламентське видавництво, 2011. С. 454-455.
} 
У теорії представників утопічного соціалізму XIX ст. А. Сен-Сімона, Ш. Фур'є, Р. Оуена та інших розроблялись проблеми потреб й інтересів робочих верств населення у контексті становлення капіталістичного суспільства. Французький мислитель Сен-Сімон розвивав ідеї про передачу засобів праці державі, ліквідацію приватної власності, планове запровадження колективного господарства, загальнообов'язкову працю, асоціації науки і виробництва. На його думку, ці й інші перетворення могли б привести до рівності потреб і споживання ${ }^{33}$.

Інший представник цього напряму Ш. Фур'є стверджував, що є чотири види рухів - соціальний, тваринний, органічний і матеріальний. Згідно 3 цими видами рухів людина має відповідні потреби. Ці потреби можна задовольнити не в адміністративних чи релігійних установах, а у діях, «які грунтуються тільки на господарських чи побутових заходах і сумісні із всякою владою, без потреби у ії втручання» ${ }^{34}$.

Фур'є вважав, що у світотворенні діють три головні причини - Бог, матерія і «математика». Відповідно до цих причин соціального життя людей наявні відповідні закони, які поки що не всі відкриті та не всі реалізуються. Ці закони становлять свого роду кодекс прав та обов'язків, а також засоби їх реалізації. В основі законів - динаміка пристрастей, інтересів, потреб, які, якщо їх правильно використовувати, можуть привести до створення суспільства, яке гармонійно розвивається ${ }^{35}$.

Відомий англійський діяч Р. Оуен дійшов висновку про необхідність перетворення суспільства на основі соціалістичних ідей. Особливої уваги заслуговують його погляди на взаємодію виробництва, економічних відносин з потребами людини.

Він стверджував, що для того щоб людина стала мудрою і щасливою, потрібно, щоб вона народилась 3 новою свідомістю, яка «повинна бути звільнена від усіх неправильних ідей, які в ній укоренились. На новому фундаменті свідомості потрібно створити «правильну i хорошу надбудову». Ця надбудова повинна «тішити іiі око», задовольняти всі вимоги науки». Така побудова свідомості і науки приведе людей до щастя і задоволення необхідних потреб ${ }^{36}$.

Значну увагу проблемам задоволення людських потреб й інтересів приділяв основоположник історико-матеріалістичної парадигми К. Маркс. Він, зокрема, розглядав потребу тільки як щось таке, що формується за

\footnotetext{
${ }_{33}^{33}$ Сен-Симон А. Избранные сочинения: в 2 т. / под ред. Л.С. Цейтлина. Москва-Ленинград : Изд-во Ак. наук СССР, 1948. Т. 1. С. 118.

34 Фурье Ш. Теории четырёх движений и всеобщих судеб. Открытие всеобщих законов движения. Антология мировой философии: в 4 т. Москва : Мысль, 1971. Т. 3. С. 519.

${ }^{35}$ Там само. С. 515.

${ }^{36}$ Оуэн Р. Книга о новом нравственном мире. Антология мировой философии: в 4 т. Москва : Мысль, 1971. T. 3. C. 529.
} 
рахунок зовнішніх факторів, часто зводячи їх до матеріального виробництва. Такого роду інтерпретація спиралась на його спроби виявити характер залежностей, що існують між потребами і предметами, які забезпечують їх задоволення.

Щодо взаємозв'язку закону і людських потреб, то вчений підкреслював те, щзо закон повинен бути виразником загальних суспільних потреб та інтересів на противагу свавіллю індивіда ${ }^{37}$.

Він також зазначав, що потреби народів самі є вирішальною причиною ї задоволення ${ }^{38}$.

А. Шопенгауер, підтримуючи ідеалістичну традицію у філософії, абсолютизує роль волі в людській діяльності, зводячи виникнення потреби лише до затримки від перешкоди, виникаючої між волею і ії тимчасовою метою, які він називав стражданням, а досягнення мети - задоволенням, благополуччям, щастям ${ }^{39}$. Поза тим А. Шопенгауер відзначив факт безперервності процесу виникнення потреб.

Продовжуючи ідеалістичну лінію дослідження потреб Шопенгауера, Ф. Ніцше разом із тим указував на інстинктивний характер потреб людини ${ }^{40}$.

Однією 3 визначних постатей європейської юриспруденції другої половини XIX ст. був Р. Ієрінг. Він вважав, що суб'єктивний егоїзм і корисливий інтерес $є$ основою прагнень людини до досягнення тієї чи іншої мети, особистої користі. Притаманний людині корисливий інтерес скеровує iї дії у разі досягнення визначеної мети. Тобто свободу волі людини, а звідси й права, зумовлено наявними в суспільстві інтересами.

Егоїстичний інтерес, на його думку, шкодить суспільним відносинам, тож для його обмеження застосовується примус. Придушення егоїзму, застосування примусу здійснюється спеціальною соціальною організацією примусової влади - державою за допомогою права ${ }^{41}$.

Відомий німецький соціолог М. Вебер визначив детермінуючу роль потреби в структурі людської діяльності і поділив потреби на: релігійні, потребу в душевному комфорті, в «легітимізації щастя», в позбавленні від страждань, у спасінні, сексуально-фізіологічну ${ }^{42}$.

\footnotetext{
${ }^{37}$ Маркс К. Сочинения: в 50 т. Москва : «Государственное издательство политической литературы», 1957. T. 6. C. 259.

${ }^{38}$ Маркс К. Сочинения: в 50 т. Москва : «Государственное издательство политической литературы», 1955. T. 1. C. 417.

${ }^{39}$ Шопенгауэр А. Мир как воля и представление. URL: http://az.lib.ru/s/shopengauer_a/text_0040.shtml.

${ }^{40}$ Ницше Ф. По ту сторону добра и зла. Прелюдия к философии будущего. Соч.: в 2 т. Т. 2. Москва, 1997. C. $243,250$.

${ }^{41}$ Шульженко Ф.П., Андрусяк Т.Г. Історія політичних і правових вчень. Київ : Юрінком Інтер, 1999. C. 264-265.

${ }^{42}$ Вебер М. Избранное. Образ общества. Москва : Юрист, 1994. С. 155-203.
} 
3 розглядуваної проблематики оригінальні судження висловив на початку XX ст. український правознавець С. Дністрянський у своїй публікації «Чоловік і єго потреби у правній системі». Він охарактеризував потреби як відчуття нестачі, отримане в боротьбі за її усунення. Право, як зазначав правознавець, пов'язане не тільки із зовнішніми (ставлення людини до зовнішнього світу), а також і з внутрішніми (задовольняються силою психічного процесу всередині людини (життя людини, мислення)) потребами. Воно висловлює правила, якими регулюється суспільний лад у приватних відносинах між людьми, «та коли приватне життя людини бореться передовсім за задоволення питомих потреб, то завданням законодавців є пізнати ці потреби, і тому звернути весь державний апарат для їх збереження». Засобами задоволення потреб, на його думку, є добра (блага - Примітка A.H.) в економічному розумінні, оскільки саме у такому сенсі вони є правовим поняттям, позаяк право зобов'язане висловлювати правила про способи набуття благ для задоволення всіх потреб як індивідуальних, так суспільних.

Добра він поділяє на внутрішні (особові) та зовнішні (речові). Внутрішні (особові) добра існують у самій людині (здоров'я, сила, здібності, знання), а зовнішні (речові) перебувають поза людиною (органічні та неорганічні твори природи, праця інших людей). Внутрішні (особові) добра Дністрянський поділяє на матеріальні та нематеріальні. Матеріальні добра мають матеріальну основу і охоплюють усе, що наука природи називає «тілом». До нематеріальних благ належать особисті послуги вчителів, суддів, лікарів та ін., а також правові добра, що полягають у правових відносинах осіб і речей (право патенту, марки, облігаційні вірительства) ${ }^{43}$. Отже, наведені вище положення визначного украӥнського теоретика права дають підставу визнати, що він помітно розвинув та конкретизував наукові уявлення стосовно взаємозв'язків потреб $i$ правового регулювання.

\section{3. Новітній період}

У період Новітнього часу проблему інтересів у праві розглядав американський теоретик першої половини XX ст. Р. Паунд. Практичною метою права, як він зазначав, $є$ соціальний контроль ${ }^{44}$, примирення та гармонізація людських бажань і вимог, що стикаються і взаємодіють, людських інтересів ${ }^{45}$. Правова система не створює інтересів, а тільки визнає їх. Він розглядав інтерес як вимоги або бажання, які людська істота

\footnotetext{
43 Дністрянський С. Чоловік і єго потреби в правній системі. Розвідка з австрійського права, Часопись правнича, Львів, 1900. С. 3-6.

${ }^{44}$ Pound R. My Philosophy of Law: Credos of Sixteen American Scholars. Boston, 1941, p. 250.

${ }^{45}$ Pound R. Social Control Through Law. New Haven, 1942, p. 54.
} 
індивідуально, через групу або асоціацію прагне задовольнити, і на який через це соціальний порядок повинен зважати ${ }^{46}$. Право, за Паундом, охороняє не всі інтереси, а тільки ті, які воно визнає, і в тому обсязі, яким воно їх обмежило.

Як відзначається у вітчизняній науковій літературі, новітня соціальна і правова філософія розвивається під знаком кризи класичного раціоналізму, яка позначилася і на вивченні взаємовпливів людських потреб й інтересів, прав людини і позитивного права ${ }^{47}$.

Проблематика інтересів і права розглядалась в останній чверті XX ст., зокрема, російським юристом А. Екімовим. Він аналізував проблему сутності права 3 позиції інтересів. Вихідною категорією для нього $є$ воля пануючого класу. Однак, вважав він, вона лише більш-менш адекватно відображає інтереси, тому вивчення сутності права не обмежується аналізом такої волі, а вимагає також дослідження відповідних інтересів. I тут виникає питання про «багатоповерховість» сутності права. Якщо закріплена у законі воля пануючого класу становить сутність права першого порядку, то інтереси того ж класу - сутність другого порядку, серед яких А. Екімовим досліджувались економічні, політичні та духовні, які отримують відображення у праві. Економічні та духовні інтереси, на думку вченого, перш ніж знайти вираження в праві, повинні пройти через фільтр політичних інтересів, оскільки лише як політичні інтереси вони представлені в праві і характеризують зміст закріпленої в ньому волі ${ }^{48}$.

У вітчизняній юридичній науці помітний внесок у розроблення проблеми правового регулювання задоволення потреб зробив П. Рабінович. Він, зокрема, першим увів у науковий обіг терміно-поняття «потребовий підхід», поступово конкретизуючи і застосовуючи його до виявлення сутності праворозуміння.

Потребовий підхід постулює ідею про те, що сутність соціальних явищ становлять ті їх корисні характеристики, які можуть бути використані людиною та суспільством для задоволення їхніх потреб та інтересів. Отже, саме праворозуміння натепер визначено науковцем як відображення у людській свідомості тих властивостей «правоявищ», які $є$ корисними для задоволення потреб та інтересів людини чи суспільства ${ }^{49}$.

\footnotetext{
${ }^{46}$ Ibid. P. 66.

47 Пацурківський П.С., Гаврилюк Р.О. Алгебра верховенства права або буттєвий устрій людського світу. Право Украӥни. 2017. № 3. С. 118.

48 Экимов А.И. Категория цели в науке права. Философские проблемы государства и права. Ленинград, 1970. С. 16-19.

${ }^{49}$ Рабинович П.М. Социалистическое право как ценность. Одесса : Юрид. лит, 2006. С. 8-13.
} 
Виходячи 3 такого підходу, П. Рабінович запропонував дефініцію поняття прав людини як певних можливостей людини, котрі необхідні для задоволення біологічних та соціальних потреб ії існування та розвитку в конкретно історичних умовах, об'єктивно зумовлюються досягнутим рівнем розвитку суспільства і забезпечені обов'язками інших суб'єктів ${ }^{50}$. У цьому сенсі права людини опосередковують задоволення потреб їх носія відповідно до рівня розвитку, насамперед того суспільства, в якому ці потреби сформувалися чи в якому зазначений суб'єкт має намір їх задовольнити.

Наведені та інші так би мовити правопотребові положення оприлюднювались П. Рабіновичем у його публікаціях починаючи з 1985 p.

Російський соціолог А. Здравомислов визначив політико-правову природу потреб та інтересів вільної особистості, яка полягає у тому, що вони забезпечують оптимальний баланс у відносинах між особистістю і публічною владою, яка здійснює правотворчу діяльність ${ }^{51}$.

Російський юрист М. Барінов дійшов висновку, що конструкція майнових потреб дає змогу подивитись на проблему задоволення потреб громадян у більш широкому плані, а не тільки крізь призму майнових відносин, які виступають предметом цивільного права; а тому категорія потреб повинна розглядатися на рівні загальної теорії права як один 3 елементів механізму реалізації правових норм ${ }^{52}$.

Білоруський правознавець М. Тараткевіч зазначав, що людські потреби, на відміну від тваринної нужди, не запрограмовані в генетичному коді, а формуються прижиттєво під впливом суспільного середовища, відносини у якому регулюються правом ${ }^{53}$.

Б. Галімов та Г. Мусін відзначали, що потреба є сутнісною властивістю як органічного, так і соціального світу ${ }^{54}$.

Г. Чернобель припускав, що центральний функціональний зміст права як нормативного регулятора полягає в його призначенні бути мірилом соціальних благ ${ }^{55}$.

Потребова проблематика досліджувалась також і західними фахівцями. Визначний канадсько-американський економіст Дж. Гелбрейт стверджував, що взаємодія позитивного права i потреб полягає в розширеному

\footnotetext{
50 Рабінович П.М. Основи загальної теорії права та держави : навчальний посібник. 10-е вид, доп. Львів : Край, 2008. С. 18.

51 Здравомыслов А.Г. Потребности. Интересы. Ценности. Москва : Политиздат, 1986. С. 13-14.

52 Баринов Н.А. Имущественные потребности и гражданское право. Саратов. СГУ. 1987. С. 98.

53 Тараткевич М.В. Человек и его потребности. Минск : Беларусь, 1989. С. 13.

${ }^{54}$ Галимов Б.С., Мусин Г.Х. Биосоциосистема : опыт потребностного подхода. Уфа, 2000. С. 32.

55 Чернобель Г.Т. Право как мера социального блага. Журнал российского права. 2006. № 6 (114). C. 83-95.
} 
державному впливі на суспільні процеси для досягнення безкризового i стабільного розвитку виробництва, тобто для задоволення виробничих потреб за посередництва норм позитивного права ${ }^{56}$.

Норвезький соціолог Й. Галтунг у розділі «Права людини і людські потреби» (Human Rights and Human Needs) своєї книги виклав уявлення про загальний зв'язок між правами людини і людськими потребами.

Він зробив висновок, що у поточній ситуації $є$ потреби, які мають аналоги прав, а є також потреби, які не мають таких аналогів, що зумовлює ідею розширення концепції прав людини; поза тим існують права, які не мають аналогів потреб, що спричинює певні культурні і класові ідеї, що лежать в основі створення прав людини. Також зазначав, що одна ідентифікована потреба може бути задоволена (повністю або частково) через імплементацію кількох прав; одне право може бути інструментом для імплементації кількох потреб ${ }^{57}$.

У західній літературі набула певного поширення доктрина невід'ємних прав людини, представники якої обгрунтовують права людини, виходячи 3 парадигми егалітаризму та справедливості, в основі якої лежить пояснення всіх прав людини як іï моральних прав. Згідно 3 нею підлягають необхідному захисту основні потреби людини й інтереси, що забезпечують iï буття як людини. Базисний характер цих потреб людини ніби зумовлює той факт, що у людини на цій підставі з'являється право на хоча б певний мінімум забезпечення iї потреб, іншими словами, право на право ${ }^{58}$.

Відповідно до антропосоціокультурної теорії праворозуміння з позицій парадигми трансцендентального обміну благами між людьми він спричинюється двома атрибутивними умовами можливості людського світу, а саме: 1) буттєво сконструйованою атрибутивною націленістю людей на безперервну реалізацію ними власної автономної сутності; 2) комунікативною солідарністю. Perpetum mobile цих одвічних прагнень людей є їхні потреби у благах та життєва необхідність їх задоволення.

Визначними представниками цієї теорії $є$ О. Гьоффе, Р. Фербер та А. Маслоу. Так, О. Гьоффе зауважує, що навіть 3 посиланням на трансцендентальні потреби завдання легітимації права ще не може бути виконане повністю. Необхідно, зазначає він, показати, що існують суб'єктивні вимоги, іншими словами, суб'єктивні потреби визнання відповідних інтересів іншого.

\footnotetext{
56 Там само.

57 Johan Galtung. Human Rights in Another Key. Printed and bound in Great Britain by Marston Book Services limited. Oxford, 2004. $450 \mathrm{p}$

${ }^{58}$ Пацурківський П.С., Гаврилюк Р.О. Алгебра верховенства права або буттєвий устрій людського світу. Право Украӥни. 2017. № 3. С. 118-119.
} 
Згідно з концепцією Р. Фербера, до процедур обгрунтування фундаментальних практичних принципів (чи фундаментальних норм) необхідно додати ще один виключно важливий аспект: «безпосереднє чи опосередковане врахування життєвих потреб інших людей».

А. Маслоу називав ці потреби справжніми людськими потребами (без їх задоволення людина як вид не можлива в принципі, тим більше не можлива людина-особистість). Адже власні потреби індивіда діють на нього як природна необхідність, тому на їхні вимоги він не може не зважати. Так відбувається символічний обмін свободи індивіда на його блага ${ }^{59}$.

Що стосується сучасних українських учених, які досліджували розглядувану проблематику, то слід звернути увагу на праці, зокрема, Р. Гаврилюк і Є. Романюка. Так, Р. Гаврилюк вважає, що сучасне право як антропосоціальний феномен $є$ заснованим на свободі волевиявлення індивіда способом нормативного існування його в соціумі щодо забезпечення його особистих і суспільних потреб ${ }^{60}$.

Як вона наголошує, дуалістична природа людини (поєднання біологічного та соціального, індивідуального та суспільного) визначила $\mathrm{i}$ подвійний характер потреб людини як феномена соціального: приватні потреби і публічні потреби. Саме тому право індивіда $\epsilon$ розподільчим за своєю природою: за його допомогою виготовлений людиною продукт розділяється на дві майже завжди нерівні між собою частини: одна призначена для задоволення приватних потреб індивіда, а друга - його публічних потреб, співпадаючих із потребами інших індивідів. Таким чином, підкреслює Р. Гаврилюк, з позицій антропосоціального підходу право можна визначити як природний спосіб розподілу соціумом виготовленого людиною суспільно корисного продукту на дві нерівні частини, призначені для задоволення іiі приватних і публічних потреб ${ }^{61}$.

$€$ С. Романюк також $є$ представником антропосоціального підходу до пізнання позитивного права. Отже, він виходить з того, що право $є$ правом людини та виступає певним сегментом способу її співбуття з іншими, який має на меті забезпечення публічних потреб як відповідної людини, так $\mathrm{i}$ всіх інших членів соціуму загалом ${ }^{62}$.

Викладене вище у підрозділі дає змогу зробити стислий висновок, зокрема, про те, що з розвитком людської цивілізації суспільство-

\footnotetext{
${ }^{59}$ Маслоу А.Г. Мотивация и личность. 3-е изд. Санкт-Петербург : Питер, 2019. С. 38.

${ }^{60}$ Гаврилюк Р.А. Методологическая традиция доктрины естественного права : монография. Черновцы : Черновиц. нац. ун-т, 2012. С. 747.

61 Там само. С. 751-752.

62 Романюк С.О. Основні властивості права в контексті природно-правового та позитивістського праворозуміння : автореф. ... канд. юрид. наук. Київ : Ін-т держави і права ім. В.М. Корецького, 2013. C. 8.
} 
знавство (у т. ч. загальнотеоретичне правознавство) приділяло все більщу увагу дослідженню проблематики взаємовпливів людських потреб й інтересів та позитивно-правового регулювання.

\section{ВИСНОВКИ}

Аналіз історії філософсько-правової та загальнотеоретичної думки дав змогу виявити, що проблематика потреб відображувалася у ній у різні періоди по-різному. Античні мислителі виходили 3 природи людини i звертали увагу на іiі суспільну зумовленість. У Середньовіччі розглядалось питання про подвійну природу людини: духовну і матеріальну. Наділяючи Бога всіма людськими якостями i абсолютизуючи їх, людина зорієнтовується у своїх належних можливостях і потребах. Тому уявлення про людські здібності і потреби втілювалось в ідеї Бога.

В епоху Ренесансу та Нового часу запанувала думка про те, що людські потреби породжуються природою. Значний вплив на розуміння природи людських потреб і можливостей здійснили такі мислителі та діячі, як Ж.-П. Марат, Г.-В.-Ф. Гегель, Дж.-С. Мілль і К. Маркс. Так, одним з перших політичних діячів, які вказали на потребовий аспект позитивно-правового регулювання, був Ж.-П. Марат. Г.-В.-Ф. Гегель у своій класифікації людських потреб мало не вперше виділив в окремий різновид потреби у праві та у законі. Уявлення про роль потреб та інтересів у людській діяльності поглибили відомі представники англійського лібералізму Дж. Бентам та Дж. -С. Мілль. Так, Дж. -С. Мілль констатував той чи інший зв'язок між людськими потребами, з одного боку, та правовими явищами - 3 іншого. Значну увагу проблемам задоволення людських потреб та інтересів приділяв основоположник історико-матеріалістичної парадигми К. Маркс. Щодо взаємозв'язку закону і людських потреб він підкреслював те, що державний закон повинен бути виразником загальних суспільних потреб та інтересів на противагу свавіллю індивіда.

У Новітній період основні теорії потреб й інтересів та їх взаємозв'язку з позитивним правом та правами людини другої половини XX ст. та сьогодення зводяться до того, що:

а) потреби пов'язують людей зі світом суспільних відносин, поза якими їхні потреби не можуть бути задоволені, і більшість таких відносин врегульовується позитивним правом, яке слугує одним із засобів задоволення людських потреб;

б) право, своєю чергою, окрім того, що є інструментом задоволення потреб людини, забезпечує та сприяє їх формуванню і розвитку. Проте правом регламентуються засоби і способи задоволення не всіх потреб, а 
лише основних (фундаментальних), які, власне, втілюються в основоположних правах людини.

3 розглядуваної проблематики оригінальні судження висловив на початку XX ст. український правознавець С. Дністрянський у своїй публікації «Чоловік і єго потреби у правній системі». Він охарактеризував потреби як відчуття нестачі, отримане в боротьбі за іï усунення. Вчений помітно розвинув та конкретизував наукові уявлення стосовно взаємозв'язків потреб і правового регулювання.

У Новітній час проблему інтересів у праві розглядав американський теоретик першої половини XX ст. Р. Паунд.

У вітчизняній юридичній науці внесок у розроблення проблеми правового регулювання задоволення потреб зробив П. Рабінович. Він першим увів у науковий обіг терміно-поняття «потребовий підхід», поступово конкретизуючи i застосовуючи його до виявлення сутності праворозуміння.

Викладене дає змогу зробити стислий висновок зокрема про те, що 3 розвитком людської цивілізації суспільствознавство (у т. ч. загальнотеоретичне правознавство) приділяло все більшу увагу дослідженню проблематики взаємовпливів людських потреб й інтересів та позитивноправового регулювання.

\section{АНОТАЦІЯ}

Розділ присвячено аналізу взаємовпливів людських потреб, інтересів та правового регулювання у різні історичні періоди.

Встановлено, що:

1. Античні мислителі виходили з природи людини і звертали увагу на іiі суспільну зумовленість.

2. У Середньовіччі розглядалось питання про подвійну природу людини: духовну і матеріальну.

3. В епоху Ренесансу та Нового часу запанувала думка про те, що людські потреби породжуються природою. Значний вплив на розуміння природи людських потреб і можливостей здійснили такі мислителі та діячі, як Ж.-П. Марат, Г.-В.-Ф. Геґель, Дж. -С. Мілль і К. Маркс. Так, одним 3 перших політичних діячів, які вказали на потребовий аспект позитивноправового регулювання, був Ж.-П. Марат. Г.-В.-Ф. Гегель у своїй класифікації людських потреб мало не вперше виділив в окремий різновид потреби у праві та у законі. Уявлення про роль потреб та інтересів у людській діяльності поглибили відомі представники англійського лібералізму Дж. Бентам та Дж. -С. Мілль. Так, Дж. -С. Мілль констатував той чи інший зв’язок між людськими потребами, 3 одного боку, та 
правовими явищами - 3 іншого. Значну увагу проблемам задоволення людських потреб й інтересів приділяв основоположник історикоматеріалістичної парадигми К. Маркс.

4. У Новітній період основні теорії потреб й інтересів та їх взаємозв'язку 3 позитивним правом та правами людини другої половини XX ст. та сьогодення зводяться до того, що:

a) потреби пов'язують людей зі світом суспільних відносин, поза якими їхні потреби не можуть бути задоволені, і більшість таких відносин врегульовуються позитивним правом, яке слугує одним із засобів задоволення людських потреб;

б) право, своєю чергою, окрім того, що $є$ інструментом задоволення потреб людини, забезпечує та сприяє їх формуванню і розвитку (проте правом регламентуються засоби і способи задоволення не всіх потреб, а лише основних (фундаментальних), які, власне, втілюються в основоположних правах людини.

\section{ЛІТЕРАТУРА}

1. Мо-дзи. Критика родовой знати и конфуцианства. Антология мировой философии: в 4 т. Москва : Мысль, 1969. Т. 1. Ч. 1. С. 197-198.

2. Антифонт. Антология мировой философии: в 4 т. Москва : Мысль, 1969. Т. 1. Ч. 1. С. 320-321.

3. Лурье С.Я. Демокрит. Тексты. Перевод. Исследования. Ленинград : Ленинградское отделение издательства «Наука», 1970. 664 с.

4. Дынник М.А. Материалисты Древней Греции. Москва : Госполитиздат, 1956. 240 с.

5. Богомолов А.С. Антическая философия. Москва : Изд-во МГУ, 1985. $392 \mathrm{c}$.

6. Платон. Сочинения: в 4 т. Санкт-Петербург : Изд-во С.-Петерб. ун-та; «Изд-во Олега Абышко», 2007. Т. 3. Ч. 1. 752 с.

7. Аристотель. Сочинения: в 4 т. Москва : Мысль,1981. Т. 3. 613 с.

8. Самсин А.И. Социально-философские проблемы исследования потребностей. Москва : Высшая школа, 1987. 159 с.

9. Аристотель. Сочинения: в 4 т. Москва : Мысль, 1983. Т. 4. 830 с.

10. Августин Аврелий. Исповедь. URL: http://azbyka.ru/otechnik/? Avrelij_Avgustin/ispoved.

11. Бэкон $\Phi$. O достоинстве и приумножении наук. URL: http://www.vostlit.info/Texts/rus7/Bacon/frametext2.htm/.

12. Гольбах П.А. Избранные произведения: в 2 т. / под общей редакцией и со вступительной статьей Х.Н. Момджяна. Перевод с 
французского П.С. Юшкевича. Москва : Издательство «Мысль», 1963. Т. $1.708 \mathrm{c}$.

13. Дидро Д. Последовательное опровержение книги Гельвеция «О человеке». Соч. в 2 т. Москва : Мысль, 1991. Т. 2. С. 342-506.

14. Вольтер В. Философские повести. URL: https://fb2-epub.ru/publ/ serija_knig/serija_filosofskie_povesti_volter/2-1-0-195.

15. Історія вчень про державу і право : підручник / за ред. проф. Г.Г. Демиденка, проф. О.В. Петришина. Харків : Право, 2009. 256 с.

16. Демиденко Г.Г. Історія вчень про право і державу : навчальний посібник. Харків : Консум, 2004. 432 с.

17. Михайлов Н.Н. Потребности личности: проблемы формирования. Челябинск, 1981.99 с.

18. Кант И. Критика чистого разума. URL: https://librebook.me/ critique_of_pure_reason_.

19. Кант И Критика практического разума. URL: https://www.gumer.info/ bogoslov_Buks/Philos/kant_pr/index.php/.

20. Гегель Г.В.Ф. Философия религии: в 2 т. Москва : Издательство «Мысль», 1975. Т. 1. 532 с.

21. Фейербах Л. Лекции о сущности религии. URL: http://lib.ru/ HRISTIAN/ATH/lectures.txt_with-big-pictures.html.

22. Бентам И. Введение в основания нравственности и законодательства. Москва : «Российская политическая энциклопедия» (РОССПЭН), 1998. $415 \mathrm{c}$.

23. Політична енциклопедія. / Редкол.: Ю. Левенець (голова), Ю. Шаповал (заст. голови) та ін. Київ : Парламентське видавництво, 2011. C. 454-455.

24. Сен-Симон А. Избранные сочинения: в 2 т. / под ред. Л.С. Цейтлина. Москва- Ленинград: Изд-во Ак. наук СССР, 1948. Т. 1. 470 с.

25. Фурье Ш. Теории четырёх движений и всеобщих судеб. Открытие всеобщих законов движения. Антология мировой философии: в 4 т. Москва : Мысль, 1971. Т.3. С. 514-525.

26. Оуэн Р. Книга о новом нравственном мире. Антология мировой философии: в 4 т. Москва : Мысль, 1971. Т. 3. С. 525-534.

27. Маркс К. Сочинения: в 50 т. Москва : «Государственное издательство политической литературы», 1957. Т. 6. 761 с.

28. Маркс К. Сочинения: в 50 т. Москва : «Государственное издательство политической литературы», 1955. Т. 1. 698 с.

29. Ницше Ф. По ту сторону добра и зла. Прелюдия к философии будущего. Соч.: в 2 т. Т. 2. Москва, 1997. С. 243, 250. 
30. Шопенгауэр А. Мир как воля и представление. URL: http://az.lib.ru/s/shopengauer_a/text_0040.shtml.

31. Ницше Ф. По ту сторону добра и зла. Прелюдия к философии будущего. Соч.: в 2 т. Т. 2. Москва, 1997.

32. Шульженко Ф.П., Андрусяк Т.Г. Історія політичних і правових вчень. Київ : Юрінком Інтер, 1999. 304 с.

33. Вебер М. Избранное. Образ общества. Москва : Юрист, 1994. 704 с.

34. Дністрянський С. Чоловік і єго потреби в правній системі. Розвідка з австрійського права. Часопись правнича. Львів, 1900, Р. 10, С. 1-36.

35. Pound R. My Philosophy of Law: Credos of Sixteen American Scholars. Boston, 1941. $250 \mathrm{p}$.

36. Pound R. Social Control Through Law. New Haven : Yale University Press, 1942. $188 \mathrm{p}$.

37. Пацурківський П.С., Гаврилюк Р.О. Алгебра верховенства права або буттєвий устрій людського світу. Право Украӥни. 2017. № 3. С. $112-125$.

38. Экимов А.И. Категория цели в науке права. Философские проблемы государства и права. Ленинград, 1970. С. 52-57.

39. Рабинович П.М. Социалистическое право как ценность. Одесса : Юрид. лит, 2006. 167 с.

40. Рабінович П.М. Основи загальної теорії права та держави : навчальний посібник. 10-е вид, доп. Львів : Край, 2008. 224 с.

41. Здравомыслов А.Г. Потребности. Интересы. Ценности. Москва : Политиздат, 1986. $223 \mathrm{c}$.

42. Баринов Н.А. Имущественные потребности и гражданское право. Саратов : СГУ, 1987. $191 \mathrm{c.}$

43. Тараткевич М.В. Человек и его потребности. Минск : Беларусь, 1989. 205 c.

44. Галимов Б.С., Мусин Г.Х. Биосоциосистема: опыт потребностного подхода. Уфа : Баш. гос. ун-т, 2000. 284 с.

45. Чернобель Г.Т. Право как мера социального блага. Журнал российского права. 2006. № 6 (114). С. 83-96.

46. Johan Galtung. Human Rights in Another Key. Printed and bound in Great Britain by Marston Book Services limited. Oxford, 2004. 450 p.

47. Маслоу А.Г. Мотивация и личность. 3-е изд. Санкт-Петербург : Питер, 2019. 400 с.

48. Гаврилюк Р.А. Методологическая традиция доктрины естественного права : монография. Черновцы : Черновиц. нац. ун-т, 2012. 788 с. 
49. Романюк Є.О. Основні властивості права в контексті природноправового та позитивістського праворозуміння : автореф. ... канд. юрид. наук. Київ : Ін-т держави і права ім. В.М. Корецького, 2013. 20 с.

\section{Information about authors:}

Rabinovych P. M., Doctor of Law, Professor of the Department of Theory and Philosophy of Law Ivan Franko National University of Lviv 14, Sichovykh Striltsiv str, Lviv, 79000, Ukraine Nakonechna A. M., Assistant of the Department of Theory and Philosophy of Law Ivan Franko National University of Lviv 14, Sichovykh Striltsiv str, Lviv, 79000, Ukraine 